\title{
THE MARGI VOWEL SYSTEM AND LABIOCORONALS
}

\author{
Ian Maddieson \\ UCLA
}

\begin{abstract}
The vowel system of Margi, described by Hoffman [1963] as containing three high vowels and one low vowel, is reinterpreted as a two-vowel system with underlying contrast only of high versus low. A pervasive contrast of secondary articulations on consonants spreads features of rounding and backness to contiguous vowels, giving rise to the different high vowel qualities recognized by Hoffman. A morphological role for the secondary articulations can be identified. Given this new understanding of the vowel system, the claim that "labio-coronal" elements in Margi are single complex segments requires reevaluation. Arguments advanced by Sagey [1986] are shown to proceed from a wrong interpretation of a syncope process and an assumed underlying contrast between high vowels. Phonetic data and the absence of phonological arguments to the contrary suggest that the labiocoronal elements are consonant sequences.
\end{abstract}

\section{Introduction}

The languages of the Bura-Margi subgroup of Chadic have achieved a certain notoriety among linguists for their supposedly complex consonantal inventories. Their chief claim to fame comes from the fact that they have been reported to have unitary segments which combine a bilabial articulation with an alveolar or palatal one ("labiocoronals"). However, these languages also have vowel systems with rather interesting properties. We will show below that Margi is appropriately analyzed as having an underlying contrast of only low vs. high in its vowel system. This understanding of the vowel system throws new light on the question of the analysis of the labiocoronals as units or as consonant sequences. The reanalysis also brings into focus similarities in the vowel systems of Margi and certain other Chadic languages. 
The source of the data to be analyzed here is Hoffman's Grammar of the Margi Language [Hoffman 1963], which is the basis of the numerous secondary studies of points in Margi phonology. 1 Paragraph numbers cited in this paper refer to the paragraphs of Hoffman's book. I have also listened to recordings of two speakers producing examples of phonological contrasts selected from Hoffman for Ladefoged's Phonetic Survey of West African Languages [Ladefoged 1968].

\section{The Margi Vowel System}

2.1. Secondary articulation and vowel distribution. The vowel system of Margi is given by Hoffman as including six contrastive vowels, i, ə, $u, e$, $\circ$, a. It should be noted that " $\theta$ " is used here, as by many other Chadic scholars, to represent a high central vowel which might otherwise be represented by $[\dot{t}]$. The two mid vowels $e$, $\circ$ occur only in a few recent loanwords and as occasional simplifications of sequences which Hoffman writes ia and wa or ua respectively. A reinterpretation of these sequences will be given below. In view of the marginal status of mid vowels, they will be ignored in the following discussion. Hoffman suggests that the remaining four vowels, low a and high $i, \partial, u$ are phonemic. In a reanalysis of Hoffman's material, Schuh [1971] noted some redundancies in the distribution of the high vowels and argued that only $a, i, u$ are really contrastive. He suggested that $\partial$ can be regarded as an epenthetic vowel "needed solely to preserve proper syllable structure" when no other vowel appears in a position where a vowel is required. In fact, the redundancies in high vowel distribution are more extensive than those which Schuh noted, allowing an analysis to be made in which there is only a contrast of low vs. high vowels. While one of these vowels could be regarded as completely underspecified (Pulleyblank [1986], Archange1i \& Pulleyblank [1986], Steriade [1987]), we will show below that the vowel position itself is not predictable. We will show that these two underlying vowels both va-

${ }^{1}$ Additional primary data would be highly desirable on a number of points, but is unfortunately not available to the author at this time. 
ry quite considerably in quality, depending on their environment. Hoffman and Schuh both treat much of the high vowel variation as phonemic, but consider the low vowel variation to be allophonic.

We will begin our presentation, as Schuh does, with the situation after velars. Velar stops and fricatives occur in plain, labialized, and palata1ized, i.e. fronted, variants before the low vowel. Examples are given in (1). We use superscript $w$ and $y$ to indicate labialization and palata1ization.

\section{(1)}

voiceless

stop

voiced

stop

voiceless

fricative $(x)$

voiced

fricative $(\gamma)$

(g) labialized

kwàkwá 'impotent person'

$$
\text { plain }
$$

kàkàdà 'book'

gà 'and '

xá

yà

'waterpot'

gwá 'enter'

palatalized

We take these examples as providing prima facie evidence that labialization and palatalization are contrastive features of the Margi consonant system (at least for velars). Although the low vowel is written with a single symbol a, Hoffman reports that it is fronted to [æ] in the environment of the palatalized velars and is backed and rounded to [o] with labialized ones ( $\$ 18)$. Hence, we see that these secondary consonantal articulations have considerable influence on vowel quality. As for the high vowels, Hoffman largely writes only $i$ after palatalized velars, only $\partial$ or $u$ after plain velars and no high vowels at all after labialized velars. What Hoffman regards as "plain" velars before u are actually produced with rounding. Given these phonetic facts and distributional limitations, we can interpret the three syllables in $(2 a)$ as having the same underlying high vowe1, but as differing by the secondary articulation of the consonant. The secondary articulations result in allophonic variation of this high vowel parallel to that noted for the low vowel, i.e. their underlying forms can be written as in (2b): 
$\begin{array}{llll}\text { (2) a. }\left[k_{\partial}\right] & {\left[k_{u}\right]} & {\left[k^{y} i\right]} \\ \text { b. } / k ə / & / k^{w} / & / k^{y_{\partial}} /\end{array}$

The analysis of such forms as having a secondary articulation contrast rather than contrasting vowels is more than simply a way of expressing distributional redundancies. Examination of suffixation processes where the suffix begins with a low vowel show that it can be motivated by rule generality. One relevant suffix is the definite marker -ári which can be added to most nouns $(\$ 71-8)$. Before this suffix, a final vowel is elided, as in (3).

(3) fá 'year' + ári $=$ fárì
màlà 'woman' + árì $=$ màlárì
sò 'thing' + árì $=$ sárì
màlmà 'village' + ári $=$ mòlmári

Let us now examine some words with velar consonants. If we assume the words in (4) have the structure that we assign them in the first column, all the suffixed forms in both (3) and (4) are directly produced by deleting the final vowel and adding the suffix. If we assume these words have the forms in the second column, as given by Hoffman, then exceptionally $u$ is not deleted but instead is desyllabified, or causes a secondary articulation to remain on the consonant as it is deleted; no simple and general rule can be formulated to cover all the suffixation cases.

\begin{tabular}{|c|c|c|c|c|c|}
\hline (4) xyà & 'dog' & xyà & + ári & $=$ & xyári \\
\hline$k y_{\partial}^{\prime}$ & 'compound' & $k y i$ & + árì & $=$ & kyárì \\
\hline kWó & 'goat' & kú & + árì & $=$ & kwárì \\
\hline xwə̀ & 'grave' & xù & + ári & $=$ & xwárì \\
\hline tágwó & 'horse' & tágú & + árì & $=$ & tágwári \\
\hline bìkà & 'sin' & bikà & + ári & $=$ & bikkári \\
\hline
\end{tabular}

Let us assume that velars in general are characterized as [dorsal]; labialized velars have the additional feature [+round] and palatalized velars the feature [-back]. The quality of high vowels is then described by the same feature spreading rules that account for variation in /a/ . We may 
write these rules quasi-formally as in (5). 2

(5) a.

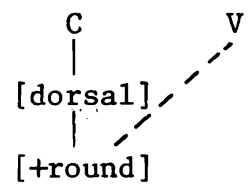

b.

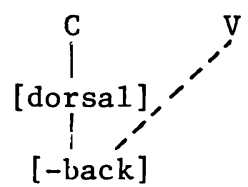

Only an opposition of high vs. low vowel needs to be posited for these rules to generate all the correct vowel variants after velars, namely, for high vowels $[\partial, i, u]$, and for low vowels $[a, æ, p]$.

Before turning to consonants at other places of articulation, it would be appropriate to discuss why an analysis with underlying secondary articulations on velar consonants is preferable to a possible alternative in which the secondary articulations are derived from neighboring vowels. This alternative would retain the assumption that there is an underlying contrast of front, central and back high vowels and posit rules which spread features from $/ u /$ and $/ i /$ to preceding velars to produce the rounded and fronted variants. Before low vowels, $/ \mathrm{u} /$ and $/ \mathrm{i} /$ would also spread features to the low vowel and desyllabify or delete. This analysis would posit underlying forms like (6a) in place of those given in (2b), and would posit the forms in (6b) in place of $/ \mathrm{ka} /, / \mathrm{kWa}^{\mathrm{wa}}$, and $/ \mathrm{k}^{\mathrm{ya}} /$.
(6) a. kə
ku
$k i$
b. ka
kua
kia

Although this alternative results in positing a smaller set of consonant contrasts, it does so at the cost of increasing the vowel inventory and having a more complex set of rules. Moreover, all vowels in the larger inventory would have limited distributions: $/ \mathrm{u} /$ and $/ \mathrm{i} /$ but not $/ \partial /$ can appear before $/ a / ; / a /$ cannot precede any high vowel; $/ \ni /$ cannot appear

${ }^{2}$ For the sake of simplicity the feature [+round] is shown in (5) as attached below the [dorsal] node in the feature hierarchy [Clements 1985]. This should not be taken to indicate that this is its proper place in a fully developed representation. Neither should this representation be taken to imply a considered position that [round] is not a univalent feature which is present or absent, rather than a binary feature. 
after $/ u /$ or $/ i / / 4 /$ and $/ i /$ cannot combine with each other in either order; there are no geminate vowels. While these restrictions are not hard to state, they do not form a coherent pattern. The permitted sequences are just those required to derive secondary articulations on consonants before low vowels and they never surface as actual vowel sequences. No statements restricting vowel co-occurrence are required under an analysis in which consonants bear contrastive secondary articulations and the canonical syllable has only a single vowel mora. Since Margi shows no evidence of being sensitive to moraic structure of the rhyme-unlike Hausa for example (Carnochan [1951], Newman [1972]) where a long vowel or diphthong may not precede a tautosyllabic consonant-the single mora account seems the appropriate one. Restriction to a single vowel mora naturally rules out all vowel sequences. The assumption that there is only a high/low vowel contrast accounts for the absence of the phonetic syllables *[kwi], ${ }^{*}\left[k^{w} \partial\right],{ }^{*}\left[k^{\gamma_{u}}\right]$, and ${ }^{*}\left[k^{y_{\partial}}\right]$ (as well as ${ }^{*}\left[k^{w_{\circledast}}\right]$ and ${ }^{*}\left[k^{y_{0}}\right]$ ).

We have shown a strong motivation for a reanalysis of the vowel system in connection with velar consonants. But this analysis would not be tenable if it did not also apply to consonants at other places of articulation. Hoffman recognizes a series of labialized labials before low vowels, e.g. in /bwàn/ 'hip', / Gwà/ 'cook (v.)', /fwà/ 'pool', /mwàl/ 'friend'. These words also have the rounded $([D]$ ) allophone of $/ a /$ (\$18). In Hoffman's notation, the labialized labials never occur before $\partial$ or before $u$. Again, there is a distributional gap. By examining, for example, some verbal derivation patterns, we may see justification for analyzing syllables like those in (7a) as having the structure in (7b).
(7)

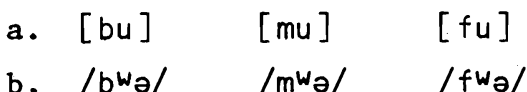

A transitive and usually benefactive verb can be derived from an intransitive by suffixing -òri . This suffix is seen in full after consonant final stems, as in (8a), but after stems with high vowels, the vowel before the $/ r /$ has a phonetic shape which is consistent with the assumption that its quality is determined by contrastive labialization with labials, as in 
(8b). After a labialized labial the vowel [u] appears, after a plain labial the vowel is [ə] .

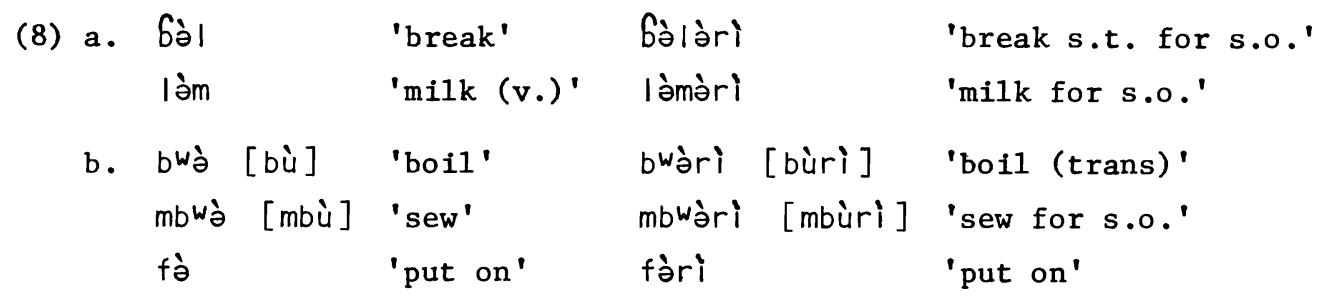

This pattern does not determine for us if the stem vowel has been preserved, replaced by the suffix vowel, or if the two have coalesced. ${ }^{3}$ But it is clear that a phonetic string such as [bwori] is not derived, when that would have been a possible outcome. These observations and the distributional facts suggest that labialized bilabials occur in Margi before both low and high vowels and that they determine the quality of contiguous vowels.

Can we complete the parallel with velars by showing that palatalized labials also occur? Hoffman does not recognize them in his phoneme inventory, but there are at least two indications that we should assume their existence. He does recognize a diphthong written 'ia', which he describes as "a close sequence of ' $i$ ' and ' $a$ '" (\$19). He writes only a single tone-mark for syllables with this diphthong. There are no other diphthongs whose first element is ' $i$ '. And the vowel $/ a /$ in this context has the same fronted allophone as appears after palatalized velars. Let us assume that when this diphthong appears after a labial, as in Gíabía 'chaff', we have a palatalized labial before the low vowel a, and when labials occur before $i$ alone we have a palatalized labial before the single high vowel $/ ə /$. What does this predict? Among other things, it would predict that a palatalized labial before the definite suffix -ári should behave like the velars in (4b), i.e. the final vowel of the noun will delete and the second-

${ }^{3}$ When the stem ends with a low vowel, the stem-final vowel remains. Taken together with the patterns seen with the ári suffix, this suggests that $/ a /$ in general is the vowel which survives when two adjacent vowels of different height are reduced to one. 
ary articulation on the consonant remain. This is what we see in examples like the word meaning 'water'. Hoffman gives the forms in (9a). His account is that the vowels $i$ and a coalesce to form the diphthong ia (\$38). But, in view of the behavior of the examples in (3) and (4), if $/ \mathrm{i} /$ at the end of 'water' was an underlying vowel, we would expect it to simply delete, yielding the definite form ?ímári. We suggest the process is as shown in (9b), where the secondary articulation is retained on the consonant.
(9) a. Pímí + -árì = ?ímíarì
(Hoffman \$74)
b. ?ímyá + -árì = ?ímyårì

Since the behavior here is parallel to that of the velars, the assumption of contrastive palatalization of labials seems justified. Note that examples such as /bikà/ in (4) above would thus be interpreted.as /bỳ̀kà/ .

The remaining major place grouping of consonants are the coronals, i.e. alveolars and palato-alveolars. One might expect the palato-alveolars to be the palatalized counterparts of the alveolars. If we further assume that consonants have only one secondary articulation, then we would expect that while labialized alveolars would occur, there would be no labialized palato-alveolars. Hoffman includes labialized $\mathrm{s}^{\mathrm{w}}$ and $t^{\mathrm{w}}$ before low vowels in his inventory of consonants in apparently monomorphemic words such as /swàn/ 'femur' and /twàn/ 'log', but no examples of labialized palato-alveolars. However, before high vowels we find both, say, /s/ and / / / before $u$ as well as /s/ before $i$. Alternations with the -ári suf$\mathrm{fix}$, as in (10), suggest that secondary articulations are to be associated with these consonants.

$$
\begin{aligned}
& \text { (10) tyò [tì] 'mourning' }+ \text {-árì = tyărì }
\end{aligned}
$$

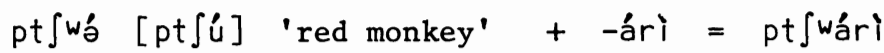

We therefore assume that the contrast of plain, palatalized, and labialized also extends to alveolars in Margi. Note that we henceforth assume that the syllable [ri] is underlyingly, $/ r^{y_{\partial} /}$, so the $\operatorname{suffix}^{4}$ we have been 
hitherto writing as -árì will be written below as -árỳ̀ .

Palato-alveolars may be contrastively labialized, but it is unclear if they can be contrastively palatalized. The vowel /o/ appears as [i] before a palato-alveolar or after one, unless it is in utterance-final position. Thus $/ \int \partial /$ is phonetically $\left[\int i\right]$ everywhere except in final posi-

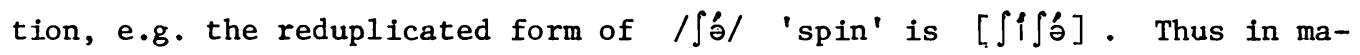
ny positions there could be no contrast between, say $/ \int /$ and $/ \int y /$, since the distinction would be neutralized. The pre-pausal allophone of /a/ is actually a partly rounded central vowel which in a narrower transcription might be written $[0]$. This allophone occurs in final position after palato-alveolars. But Hoffman also cites a few forms in which he writes $i$ in final position after a palato-alveolar consonant, such as Jifi 'hair'. If these are not errors, in which a non-final form was written in place of a citation form, then there is at least a limited contrast of palatalization with palato-alveolars. Whatever the solution to this problem is, we must represent the fact that their "plain" versions are in some sense inherently palatalized, e.g. they are underlyingly [-back], but differ from palatalized alveolars in not being [apical].

The three-way contrast between plain, palatalized and labialized also applies clearly to glottal stops. Hoffman partly noted this. In his 1ist of consonants ( $\$ 20)$, he includes glottal stop (?) as well as a "glottalized bilabial semi-vowel" ( $(W)$ and a "glottalized palatal semi-vowel" (?y). He then comments that "while? before a seems to be a phoneme by itself, ? before $u$ and $i$ is an allophone of ${ }^{W}$ and $? Y$ respectively". That is, there is no contrast between $2 y_{i}$ and $2 i$ or between ${ } w_{u} u$ and $3 u$. Examples illustrating the secondary articulation contrast with /?/ are given in (11), with Hoffman's forms in parentheses where they differ.

with what Hoffman writes as $r i$. The frequency of the vowel $i$ after $r$ in this position makes it seem likely that the front vowel quality could be predicted from some other principle, particularly since final i in suffixes of this kind changes to $\partial$ or deletes in non-final positions $(\$ 37)$. 


\section{(11) à?á 'no' u?wa 'breast, milk' zyà [?ìa] 'thigh' \\ ใwò [?ù] 'grind' ใYò [?i] 'do' \\ ? Yómy’́ [?imi] 'water'}

We thus see that at all major places of articulation in the Margi consonant system, the consonants may appear plain or bear a secondary articulation of palatalization or labialization. There are no contrasts between high vowels of different qualities. Instead, high vowel allophones are predictable from the secondary articulation phenomena. When this is understood, the distributional assymetries between consonants and vowels reported by Hoffman are accounted for.

There remain, of course, a number of details which need to be worked out in the interpretation of the Margi phonological system. For example, the glides $w$. and $y$ clearly count as [+round] and [-back] respectively and these features spread to the following vowel, e.g. pre-pausal yò

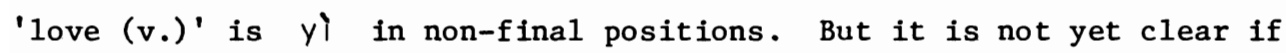
their palatalized and labialized counterparts $w^{Y}$ and $y^{W}$ would need to be posited, and, if so, how these would differ from each other. Hoffman does write syllables such as $w i$ and $y u$, which we might wish to inter-

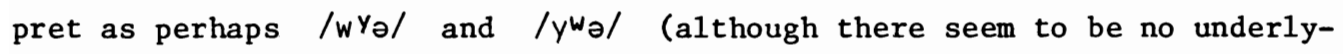
ing forms with $y u$ ). This notational distinction doesn't seem to have any meaningful interpretation, creating a problem for deriving the vowel qualities $i$ and $u$ after $/ y /$ and $/ w /$ by the same rules we have discussed. There are indications that $/ y /$ and $/ w /$ can appear postvocalically; hence, the syllables $w i$ and $y u$ might also be considered to have the structures /wəy/ and /yow/, with the vocalic quality occurring through anticipation of the final glide. A relevant item to consider is the word for 'tail', given by Hoffman as [ $\int u ́$ ], as shown in (12). Unlike previously cited examples, this word does not delete its vowel before the -árỳ̀ suffix.

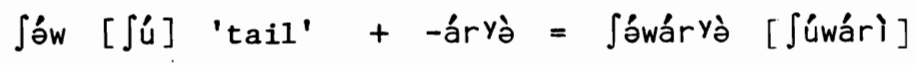

By positing a postvocalic / $\mathrm{w} /$ in its underlying form, we account for the unexpected behavior of this word. But because the data is incomplete it is 
unclear if the $w i$ and $y u$ syllables can be shown to have a motivated interpretation as /woy/ and /yow/.5

Note that although $/ \int /$ is followed by $[u]$ in (12), the consonant is not marked as labialized. We do not need to assume that the prevocalic consonant has distinctive labialization if the [+round] value of the $/ \mathrm{w} /$ is spread back to the vowel which precedes it. This kind of anticipatory assimilation can be readily found elsewhere in Margi. We observe alternations between $\partial$ and $u$ across word boundaries when a [+round] consonant follows the word boundary, as in (13a), and in derivational processes such as those creating abstract nouns with the suffix $/ k^{w} \grave{r} /$ ([kùr]) in (13b).

\begin{tabular}{|c|c|c|c|c|c|c|c|}
\hline \multirow{4}{*}{\multicolumn{2}{|c|}{ (13) $a$}} & $\begin{array}{l}\text { ànó } \\
\text { də̀ }\end{array}$ & $\begin{array}{l}+ \\
+\end{array}$ & $\begin{array}{l}\eta k^{w a ̀ ~} \\
\text { wàgò }\end{array}$ & $\begin{array}{l}\rightarrow \\
\rightarrow\end{array}$ & $\begin{array}{l}\text { [ànú okwà ] } \\
\text { [ dù wàgà] }\end{array}$ & $\begin{array}{l}\text { 'for daughter' } \\
\text { 'in the evening' }\end{array}$ \\
\hline & & mdə̀ & + & kwə̀r & $\rightarrow$ & [mdùkùr] & 'friendliness' \\
\hline & & bə̀lkə̀ & + & kwòr & $\rightarrow$ & [bòlkùkùr] & 'ignorance' \\
\hline & & yə̀ & + & kwə̀r & $\rightarrow$ & [ yùkùr] & 'love' \\
\hline
\end{tabular}

In the examples in (13a) Hoffman sees the $\partial$ vowels as being influenced by the labialized (or labial-velar) consonant which follows across the word boundary; in (13b) he sees the vowels as being influenced by the rounded vowel in the derivational suffix. In our view, both sets of examples in (13) illustrate a single process, namely, that a high vowel before a labialized consonant may become rounded by anticipation of the labialization of the consonant. Note that what Hoffman. writes as $u$ after $y$ in the word for 'love' in (13b) is actually a high front rounded vowel which he says is similar to the French or German vowel $\ddot{u}$ (IPA [y]). In other words, this vowel takes on the palatal quality of the preceding consonant and the labial quality of the following $/ \mathrm{kw} /$. The vowel $\mathrm{u}$ in $/$ Jow/ 'tail' has a similar quality ( $\$ 18)$. These facts provide support for interpreting a possible syllable yu in isolation as /yow/.

${ }^{5}$ See footnote 7 for evidence that some non-glide consonants which are both labialized and palatalized may be derived in Margi. These are not ambiguous in the way that $W^{y}$ and $y^{W}$ are, hence they do not provide a problem for our analysis. 
A parallel anticipation of frontness also occurs before palatalized consonants, although this process is obscured by Hoffman's transcriptional practices. He notes that before palatalized velars, palato-alveolars, and $y$ the vowel a "resembles a short open i [as in] English bit" (\$18). This is the same allophone that he gives for his "phonemic" $i$ in wordmedial positions. But he continues to write $\partial$ in these contexts, whereas after palatalized velars, palato-alveolars, and $y$ he writes $i$, not $\partial$. The spreading rules in (5) above can be revised to describe both anticipation and perseveration, as in (14). The rules are also simplified to eliminate their restriction to dorsal consonants.

(14) a.

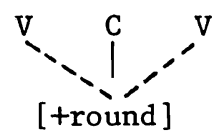

b.

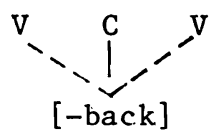

2.2. Morphological arguments for a reduced vowel inventory in Margi. Although the interaction of secondary articulation and vowel qualities provides the principal basis for positing a reduced vowel inventory in Margi, there are some morphological arguments which support this analysis. Hoffman notes that the majority of verb stems begin with a consonant but a few begin with the vowels $i$ or $u$ whereas "there are no examples for verb stems beginning in $a$ or any other vowel" (\$211). In other words, verb stems do not begin with $\partial$ or $a$. This restriction receives an explanation if we assume that Hoffman's "vowel initial verbs" actually begin with underlying / $/ \mathrm{y} /$ or / $/$ a/ . Note that in non-final forms where the phonetic quality of $/ \partial /$ has not been affected by a following consonant's secondary articulation to produce a front rounded vowel, the glide + vowel sequences / $/ \mathrm{y} /$ and / wo/ can be heard simply as [i] and [u]. A good example is provided by the first person singular subject pronoun. In final suffix position this is [yə], but in prefix position it is [i] (\$112113) unless the verb stem is preceded by $/ a /$ as in the "short subjunctive" when it will surface simply as $[y]$ (\$333). All verb stems thus begin with consonants, and the absence of initial $a$ or $\partial$ is a consequence of that requirement. It is still true that the set of verbs which Hoffman re- 
gards as vowel initial behave differently from other verbs. For example, the final vowel of a tense/aspect marker ending in $/-a /$ is deleted when it precedes these verbs, but not otherwise. The class is still well-defined as it is the class of verbs which begins with a glide followed by the high vowel $/ a /$.

More fundamental are the processes I will refer to as morphological palatalization and labialization. These are derivational processes which Hoffman describes as involving suffixation with $/-i a /$ and /-wá/ respective$1 y .(\$ 220, \$ 240)$. The first gives a more completive meaning to the verb, the second generally involves an idea of separation. Hoffman's descriptions of the processes are fairly complex and not always observationally correct. If they are reinterpreted as involving palatalization or labialization of the final consonant in the stem, and replacement of the final stem vowel with $/-a /$, a simpler and more explanatory account is obtained. We will simplify our discussion by remaining silent on some differences in the tonal patterns of the two processes.

Some examples of verbs which undergo both of these processes are given in (15).

(15)

\begin{tabular}{|c|c|c|c|c|c|}
\hline 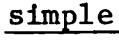 & $\mathrm{CEM}$ & palat & zed form & 1abiali & zed form \\
\hline bBว̆ & 'forge' & $b B^{Y a}$ & 'forge' & bghă & $\begin{array}{l}\text { 'forge } x \text { instead } \\
\text { of } y^{\prime}\end{array}$ \\
\hline f̀̀ & 'put' & fyá & 'put down' & fwá & 'put into' \\
\hline pàष̇̀ & 'break' & páqyá & 'break open' & póqwá & 'break in two' \\
\hline qà & 'cut' & qyá & 'cut off' & qwă & 'cut in two' \\
\hline ntà & 'split' & nt Yá & 'split' & ntwá & 'split in two' \\
\hline tsàxə̀ & 'sweep' & tsáxyá & $\begin{array}{l}\text { 'sweep } \\
\text { together' }\end{array}$ & tsáxwá & 'sweep into' \\
\hline
\end{tabular}

A further set of examples which Hoffman only cites as undergoing the palatalization process is given in (16).
(16) simple stem
palatalized form
tsà?wò [tsà?ù]
tsá?wyá 'incise'
(tsá?wía)
dàgwò [dùgù]
dàgwyá 'attack'
(dùgwla) 
simple stem

ngà
ngỳ̀ [ogyì ]
$t \int \grave{a}\left[t \int \hat{\imath}\right]$

'bend'

'burn'

'hem' palatalized form

ngyà 'bend down'

ngyá 'fire (pottery)'

t $\int a ́$ 'hem'

Hoffman's description of the suffixation with $/-\mathfrak{i}$ / involves essentially three processes: deletion of final a before adding $/-\mathfrak{l} a /$, e.g. 'cut' or 'split' in (15); changing of final $u$ to $w$, e.g. 'incise' and 'find' in (16); and "if /-ía/ happens to follow after a velar", palatalization of that velar, e.g. 'bend' in (16). He does not mention that $\partial$ is deleted also. Our account of these facts is that the morpheme in question consists of a floating [-back] feature, which docks to the last consonant in the stem, and a low vowel, which replaces the final vowel (if any) or is suffixed to stems which end in a consonant. Final $u$ does not occur except after a labialized consonant, so rather than the vowel changing into $w$, what we see is the retention of the [+round] feature of the consonant. It may also be significant that only one of Hoffman's examples of verbs which undergo this process has a stem-final vowel which he regards as phonemic $i$, i.e. has a last consonant which is palatalized. We think it likely that such verbs rarely undergo this process because their derived forms would be homophonous with verbs with the corresponding plain consonant. ${ }^{6}$

The process involved in the labializing derivative is similar. A final stem vowel is replaced by /a/, and a floating [+round] feature docks to the last consonant of the verb stem, as the examples in (15) illustrate. ${ }^{7}$

${ }^{6}$ Note that verbs with palato-alveolar consonants are not prevented from undergoing the process. These consonants do not have an underlying contrast with respect to the feature [back], as noted above. Hence, although docking [-back] to these consonants is vacuous, no underlying contrast between different verb stems is obscured by the derivation process. The examples that Hoffman gives all have high vowels, hence the derived form differs from the simple verb stem in that a low vowel occurs after the palato-alveolar consonant .

${ }^{7}$ It may also be the case that these processes derive some consonants which are both labialized and palatalized, as in the case of the labialized derivative of the verb nàxyə̀ 'trample', nàxywá 'trample to bits'. We 
In some derived disyllabic forms the effect of the [+round] feature spreads into the syllable preceding the last consonant. Examples are given in (17).

(17)

\begin{tabular}{l} 
simple stem \\
\hline bdál 'lock' \\
ntákó 'divide' \\
bál 'break'
\end{tabular}

labialized form

bdàlwá [bdùlwá] 'set (bone)'

ntákwá [ntúkwá] 'divide in two'

Gálwá [Gùlwá] 'break in two'

These forms provide further evidence that the vowel quality $u$ may result from assimilatory influence on a high vowel from a following labialized consonant as well as from a preceding one. This anticipatory influence is apparently less regular than the perseverative one. Hoffman's data does not make clear if it is an optional process or if the cases he cites are lexically restricted. Whichever is the case, what is important is to note that a phonetic string such as [ntúkwá] might have either of the structures shown in (18).

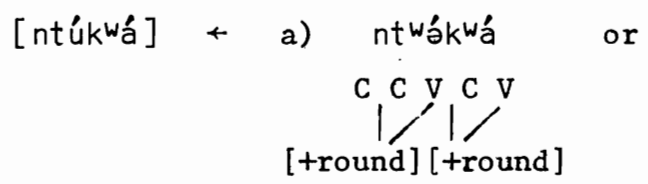

or

b) ntákwá

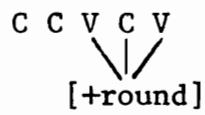

2.3. Parallels with other Chadic languages. Restricted vowel inventories and morphological processes involving "floating" palatalization and labialization are not isolated phenomena in Margi but recur in a number of other Chadic languages. Among the closer relatives of the Bura-Margi cluster within Central Chadic, both Higi [Mohrlang 1972] and Gufe [Hoskison 1974] have vowel systems with major similarities to Margi. Only a high/low contrast is observed for medial vowels in Higi and for vowels in any position in Gufe. Phonetic vowel quality varies considerably under the influence of properties of neighboring consonants in both languages, being fronted in the environment of palatalized consonants and rounded in labialized environments. Hoskison also notes two verbal processes involving morphological

\footnotetext{
will not elaborate on this possibility at this time since it goes beyond the central points of this paper.
} 
palatalization in Gufe. One, which derives a verbal form indicating motion toward the speaker, replaces the stem final vowel with a low vowel and docks palatalization on the nearest stem consonant with the highest ranking on an eligibility scale. Morphological palatalization is also described for Zulgo [Haller 1980] and Podoko [Jarvis 1981]. Among West Chadic languages, Bade and Ngizim have only a high/low vowel contrast, at least in medial position [Schuh 1978]. Again, phonetic vowel quality is determined by consonantal environment. Miya [Schuh 1987] also has only a high/low vowel contrast. Morphological palatalization is a major process in deriving deverbal nouns in this language, though, unlike Gude (and Margi), it may affect more than a single consonant. Although morphological labialization is less commonly reported, it occurs in Mofu according to Schuh's reanalysis of Barreteau [1978].

These similarities show that Margi is not an unusual language within the context of Chadic. In fact, a relatively restricted vowel inventory is broadly characteristic of the entire Afro-Asiatic language family.

2.4. Underlying vowel positions in Margi. In view of the proposal by Schuh [1971] that the presence of $\partial$ can be predicted in Margi, we will briefly review the evidence for considering the vowel position occupied by high vowels to be underlyingly present. (Schuh's arguments for Margi are similar to those presented for Ngizim and Bade in Schuh [1978]). Schuh suggests that a vowel is epenthesized to break up unacceptable consonant clusters. In most cases this means that a vowel must be inserted after every obstruent. Sonorants in final position do not require a following vowel, unless they are the only consonant. These rules predict that there should be no words that contrast either in presence or absence of initial high vowels or in presence or absence of high vowels following sonorants. But such cases do occur: examples are given in (19).

(19) Unpredictability of initial and final high vowels initial high vowels

$\begin{array}{lll}\text { ámtàl '1izard' } & m \text { tàgə̀ 'bush' } \\ \text { ámpỳ̀ '1ife' } & \text { mpỳ̀ } & \text { 'winnow' }\end{array}$




$\begin{array}{ll}\text { ázwàwà 'stick' } & \text { z'̀̀lyó 'priest's assistant' } \\ \text { ásyịyi 'rope' } & \text { syídàm 'earthworm' }\end{array}$

high vowels following sonorants

\begin{tabular}{|c|c|c|c|}
\hline kWómá & 'ten' & kwə̀m & 'meat' \\
\hline màmà & 'honey' & dàm & 'pick (v.)' \\
\hline sə̀nə̀ & 'know' & bə̀| yə̀n & 'new' \\
\hline wə̀là & 'look' & ?wว̀l & 'dry (v.)' \\
\hline
\end{tabular}

We may further note that màmà 'honey' reduplicates as màmàmàmə̀ but fàm 'pick (v.)' as dàmfàm; wàlà 'look' as wòlòwòlà ( $\rightarrow$ [ùlùlà]) but ?wàl

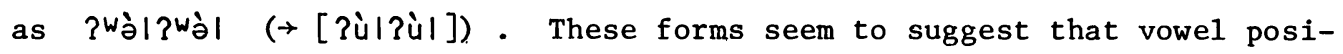
tions cannot be predicted simply from the input string of consonants in Margi.

\section{Labiocorona1s}

We are now in a position to discuss how far the new understanding of the nature of the Margi vowel system contributes to answering questions about the nature of the "labiocoronal" elements. Hoffman wrote ( $\$ 24)$ :

"A peculiar feature of Margi as well as the whole Bura-Margi group ... are the labial-alveolars, which in this respect are comparable with the labio-velars of so many languages in the West Sudan. That these labioalveolars (and the labio-alveopalatals) are simple phonemes and not casual juxtapositions of two separate phonemes can be concluded from their behaviour in reduplications."

The view that the elements in question are single segments was accepted by Ladefoged [1968] and has been widely repeated by others, e.g. Chomsky \& Halle [1968], Newman [1977]. Margi was cited by Halle [1983] as the protype of a language having segments with simultaneous labial and coronal articulation. Based on phonetic and phonological data drawn principally from Bura I have argued [Maddieson 1983] that these Chadic languages do not have complex segments of this type. Instead, these elements are sequences, that is, they consist phonetically of a sequence of a labial and a coronal articulation and phonologically of two separate feature matrices or trees linked to separate slots in the CV (timing) skeleton. However, in her recent dissertation from MIT, Sagey [1986] argues that, the phonetic data notwithstand- 
ing, there are phonological reasons in Margi to treat them as single segments. She used the convenient name "labiocoronals", proposed by Halle [1983], for these elements and I will continue this usage. Her argument that there are complex labiocoronal segments in Margi rests on two points: behavior in reduplication, a point mentioned but not elaborated by Hoffman, and word-internal syllable structure. The point has importance not only for the phonology of Margi and related Chadic languages, but also has ramifications for the structure of phonological feature systems. If Sagey's arguments can be sustained, then phonological theories must certainly be formulated so that labiocoronals are accounted for. If not, then, at the least, some other language than Margi would need to be shown to have "labiocoronal" segments before they should be recognized in theoretical models.

3.1. Reduplication. First let us examine the question of reduplication. Margi makes quite extensive use of initial reduplication in its verbal morphology. Reduplication also occurs to a lesser extent in the numeral and nominal systems. I argued in my earlier paper that reduplication could not decide the question of one vs. more segments in Margi (or Bura). This was because in the process Hoffman calls "complete reduplication" whole stems are reduplicated, and in the process Hoffman calls "partial reduplication" complete initial syllables are reduplicated. If this understanding of these patterns is correct, then reduplication provides no evidence for deciding whether the labiocoronal elements are being treated as single segments or as sequences, since in either case the entire onset to the initial syllable is reduplicated.

The verbal system of Margi uses reduplication to derive iterative verb forms from simple verbs, and to derive what Hoffman calls a participle. Although there are two different rules of reduplication, these two derivational processes are not distinguished by the type of rule used. Either may take the form of complete reduplication of the entire verb. Examples of complete reduplication are given in (20) as cited by Hoffman. 
(20) base form

Iterative formation

kútsá 'churn (milk)'

pìdà reduplicated form

kútsákútsá

pìdàpìdà '(keep) churn(ing)'

'spend the whole night'

participial formation

kùngùrà 'blister (v.)'

kùngùràkùngùrà 'covered with blisters'

tsàgàlà 'gather'

sàsù?wà 'smoke (meat)'

tsàgàlàtsàgàlà 'gathered together'

sàsù?wàsàsù?wà 'smoked'

While agreeing that complete reduplication is irrelevant to the issue, Sagey correctly disputes the claim that partial reduplication of a stem involves the complete initial syllable. She points out that there are some basic forms of words in Hoffman's grammar which consist of or contain a syllable which is not fully reduplicated in the reduplication process. Examples are given in (21).

\section{(21) base form}

iterative formation

गəे। 'to abuse'

ndàl 'to twist'

participial formation reduplicated form

jànàl 'to abuse many times'

ndàndàl 'to twist around many things'

mwàmwàl 'sour, acid'

sə̀sàl 'fried'

Də̀nว̀rż̀ 'pushed along on ground'

In (21) only the syllable onset and nucleus reduplicate; the syllable-final consonant is not reduplicated. Since less than the full syllable is reduplicated the rule must refer to segments or syllable constituents, not the entire syllable. However, the examples in (21) could be described in two ways. Assuming that all of the syllable onsets in question (including prenasalized obstruents and consonants with secondary articulations) are single segments, partial reduplication could be formulated to generate a copy of the initial consonant and a vowel. Alternatively, it could be formulat- 
ed to copy the syllable onset (which might contain a sequence of consonants) and the nucleus. If the rule is of the former type, it provides evidence for deciding if complex phonetic elements are single segments or clusters since these will be treated differently in the process. If it is of the second type, it does not provide such evidence. The data in (21) are not decisive and can be described as well by either type of rule.

Sagey believes the indeterminacy can be resolved by examining the interaction of a rule of syncope with the reduplication rule in question. The syncope process deletes a non-low vowel between a coronal consonant and a velar. (It also applies rarely between a labial and a velar, \$39.) Some examples of the resulting alternations are given in (22):

$$
\begin{array}{lll}
\text { tátàkú } & =\text { tótkǔ } & \text { '(only) one' } \\
\text { óntsàkà } & =\text { ántskà } & \text { 'stone' } \\
\text { nWazəgə?i } & =\text { nwazgə?i 'a rat' (tone not marked by Hoffman) }
\end{array}
$$

Besides the word-medial consonant clusters in the syncopated forms in (22), this syncope rule also derives some initial consonant clusters. It is these which might provide the test cases to determine how reduplication applies to undoubted clusters. We can then see whether this is the same or different from the way that it applies to labiocoronals. Sagey argues that labiocoronals differ from the clusters derived by syncope precisely in that the derived clusters "reduplicate as clusters, while the labiocoronals reduplicate as single segments" ( $\mathrm{p}$. 178). Some reduplicated forms with labiocoronals are given in (23).

(23) base form

Gdə̀ 'chew'.

ptə̀ 'be insufficient'

mnyà 'rebuke'

bdzàl 'fry'

mt đàdà 'point'

mtsàkù 'pick up' reduplicated form

Gđàbdəิ 'chewed'

ptàpt̀̀ 'insufficient'

mnYàmnyà 'rebuke very much'

bdzàbdzàl 'fried'

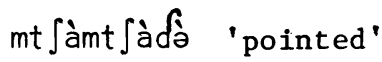

mtsòmtsàkù 'pick up in many places'

Note that in these examples all prevocalic consonantal elements in the initial syllable of the base form are reduplicated. Most words with initial 
labiocoronal elements are monosyllabic. When they have no final consonant, like the first three examples in (23), there is no direct basis on which to decide whether these are examples of complete or partial reduplication, since the results of either process would look the same. However, there are a few examples in which a postvocalic consonant is not necessarily copied, e.g. 'fry', as well as the two forms cited above which are bisyllabic. These can be more confidently seen as subject to partial reduplication and hence of relevance to the present discussion.

The two forms, cited as Hoffman gives them, which show the relationship of syncope with reduplication are given in (24).
(24) base
syncopated form
reduplicated form
sùkùdà 'push' skùdà
sàskùdà 'push bit by bit'
tsùkwà 'touch' tskwà
tsòtskwàri 'touch many things'

There is an initial cluster in the syncopated form, but crucially no initial cluster in the reduplicated form. Sagey's observations on the examples in (24) go as follows:

"...it is the syncopated form of 'to push', skùdó, that is reduplicated, because in the reduplicated form there is no vowel between the second $/ \mathrm{s} /$ and the $/ \mathrm{k} /$. Compare the derivation: tàpàrà 'to vomit' $\rightarrow$ tàtàp̀̀rà 'fo vomit many times'. If reduplication were applying to the form sùkùdá, we would thus expect *sùsùkùdà on analogy with tàtàpòrà . We cannot apply syncope after reduplication to derive sùskùdə from *sùsùkùdə̀, because we would then expect tàtàpàrà $\rightarrow$ *tàtpòrà. Note, furthermore, that the elided vowel in skùdo was a $/ \mathrm{u} /$. If this vowel were present in the form that reduplication applied to, the first vowel in the reduplicated form would also be (u/, yielding *sùskùdò, rather than the default /ə/, as in sàskùdò ." (p. 179)

This argument is critical, since these cases with syncope are the only ones which might show that Margi makes a distinction between consonant clusters on the one hand and labiocoronals and other complex consonants on the other. If syncope does not need to be ordered before reduplication, then the reduplication rule does not need to distinguish onsets of different kinds.

However, Sagey's arguments have several problems. First, she argues that if reduplication were applying to the base form sùkùd the vowel in 
the reduplicated form would be $u$. We have argued that $u$ is a variant of an underlying single high vowel element which we write /ə/. Its [tround] variant appears when [tround] has been spread from a preceding or following labialized consonant. In sùkùdò the final consonant is obviously not rounded, but the medial velar is, or the vowel following it would not be $u$. Given a labialized velar the vowel in the first syllable is 1ikely to be rounded by anticipatory spreading, as in the examples in (13) and (17) above. Hence the underlying form of sùkùdà is /sàkwùdò/. The reduplicated form to be expected from this base is /sòsòkwùdò/ .8 If the syncope rule is applied to this form the correct output is derived. Simplified derivations for the two forms in (24) are given in (25).
underlying form
by spreading rule
by syncope
base form
səkwədə
sukwudo
skwudo
tsòkwà
tsùkwà
tskwà
reduplicated form
səsəkwədə
sasukwudo
saskwudo
tsàtsàkwàri
tsàtsùkwàrì
tsàtskwàri

Note that our account not only predicts the correct vowel in these reduplicated forms but also removes a rather problematical feature of Sagey's rule ordering, which had placed syncope, a rule which derives surface phonetic alternants, before reduplication, a rule which derives morphological variants in the lexicon.

Sagey's other argument for stating that syncope cannot apply after reduplication is that incorrect syncopated forms would be derived as a result of this ordering. She cites tàtàpàrà $\rightarrow$ *tàtpòrà as a case of incorrect syncopation. This is an ill-chosen example, since the conditions for the syncope rule to apply are entirely unsatisfied; low vowels do not syncopate,

${ }^{8}$ Note that when a labialized consonant is reduplicated it determines the phonetic surface form of the vowel (especially if nonlow), e.g. the vowel in the reduplicated form of bW’̀ 'boil' [bu] must be [u]; bWə̀b'̀̀ $\rightarrow$ [bùbù]. 
and the consonant environment is wrong. Syncope only applies when the following consonant is velar and the preceding consonant is coronal (or, rare1y, labial). All the examples Hoffman gives also involve only obstruent consonants and this seems to be another condition on the rule. There are no forms in Hoffman to suggest that a properly constrained syncope rule does not apply to any case which satisfies its conditions.

Sagey's arguments from reduplication therefore fail to establish that Margi is drawing a distinction between clusters (derived from syncope) and single consonants. Hence they provide no evidence for the claim that the labiocoronal elements such as pt, $6 \delta, m n y$, etc. are being treated as single consonants, despite their complex nature.

Before leaving the topic of reduplication, there are a couple of other points worth noting. Both Hoffman and Sagey suggest that the partial reduplication rule omits any syllable-final consonants and copies only onset and vowel. Examination of Hoffman's materials shows that most of the "partially reduplicated" forms with an omitted final consonant have fuller variants with the same meaning in which the syllable-final consonant is present. A1most all involve failure to reduplicate a syllable-final ///. Examples of such duplicates are given in (26).

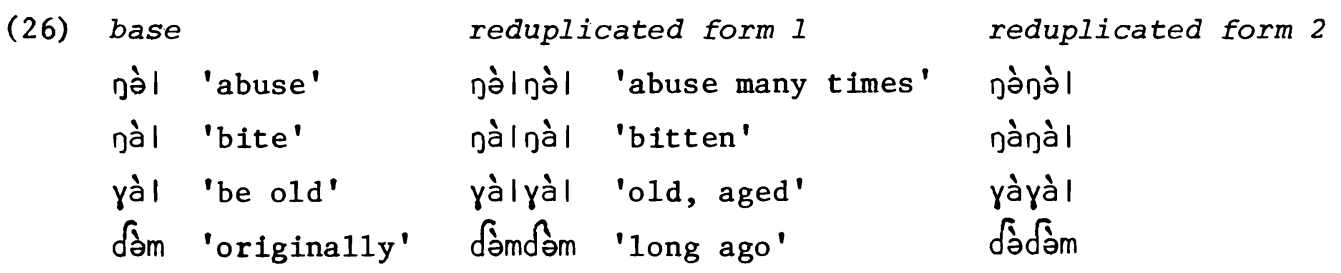

These data suggest that it should not be ruled out that the partial reduplication rule generates a copy of the entire initial syllable, as originally suggested by Maddieson [1983]. This would then be followed by application of a rule which deletes the syllable-final consonants under circumstances which are rather hard to specify from the material available at present.

The second matter concerns whether $\partial$ is a default vowel in reduplication. Hoffman describes the partial reduplication process as follows: "... only the initial (simple or compound) consonant is reduplicated, mostly 
with the vowel $\partial "(\$ 251)$. This remark implies that the vowel of the initial syllable is not copied, but instead is normally replaced with the vowel /ə/. We have already discussed the example of sàskùdô, where Sagey proposes that a default vowel is supplied in the reduplicated form but where our account specifically predicts that [ə] will occur. Apart from cases of this type, there seems to be only one example where the vowel of the stem is not copied in the reduplicated form, and that is the word for 'pick up', given in (23) above. In general, the reduplicative process copies the vowel of the base form on which it operates. If $/ \partial /$ is a default vowel it is one in a much wider sense than concerns just reduplication, since any vowel that is not /a/ can be predicted to be /ə/.

3.2. Consonant sequences and syllable structure. Sagey [1986:182-184] also suggests that there is evidence to show that labiocoronal elements are single segments from the way in which they take part in consonant sequences. One line of argument concerns prenasalized stops in medial clusters beginning with $/ r /$. This can be summarized as follows. In a sequence /-VrNSV-/ (where $\mathrm{N}$ is a nasal and $\mathrm{S}$ is a stop) NS can be considered a single segment, if homorganic, or can be considered to be two segments. In the latter case, the syllable boundary (.) might be considered to fall before or after the nasal, giving efther /-Vr.NSV-/ or /-VrN.SV-/. Sagey argues that the first placement is unacceptable since it violates sonority sequencing within the syllable, creating an onset with a nasal preceding a stop. ${ }^{9}$ And the second placement is ruled out by the facts of Margi: if the $\mathrm{N}$ is placed in the same syllable as $/ r /$ then "there is no explanation for the fact that the syllable-final nasal is in every case homorganic with the following consonant" (that is, the S). Sagey points out that non-homorganic.

${ }^{9}$ Sagey offers no other argument for dismissing this syllabification. However, language facts sometimes require that it be admitted. Russian "fleeting vowels" are sometimes deleted between an initial sonorant and an obstruent, e.g. IYéstniy 'flattering' but IYstyity 'to flatter', and the genitive singular forms of mox 'moss', lob' 'forehead' and IYod 'ice', which are mxa, Iba, and Iyda respectively. Strict adherence to sonority rules would rule out deletion in such a position. 
sequences of nasaltstop can be derived in Margi through suffixation and reduplication processes, so there is no general constraint that heterosyllabic NS sequences must be homorganic. Therefore the requirement for homorganicity in clusters with $/ \mathrm{r} /$ can only be explained if it is assumed that these NS sequences in Margi are single prenasalized segments, with a syllabification which might be represented /-Vr. $\mathrm{N}_{\mathrm{SV}} /$ /. Since the NS sequences in question include labiocoronals such as /mny/, /md/, /mt/, as in the examples given in (27), this argument is taken as contributory proof of the unitary nature of labiocoronal elements in general.

$\begin{array}{ll}\text {...ármnyá } & \text { 'at the side of' } \\ \text { áwàłoṕt Jòrmdò } & \text { 'ow1 (sp.)' } \\ \text { ármtá } & \text { 'journey' }\end{array}$

Sagey writes the labiocoronals /md/, /mt/ in (27) as /mnbd/, /mnpt/ to indicate that she considers the nasal and the stop components to be produced with simultaneous labial and alveolar articulations. If this were so, the nasal and stop elements would indeed be homorganic. However, all the phonetic evidence suggests that this supposition is not correct. Detailed phonetic evidence was given in Maddieson [1983] showing that the corresponding sequences in Bura, a language closely related to Margi, are sequences of labial followed by alveolar articulation. But Bura is not Margi, and it might be that the languages differ in exactly this area. Unfortunately, the available Margi recordings are not of a nature to allow for preparation of publication-quality figures to match those presented for Bura. 10 Nonetheless, it is clear that Margi is like Bura. In /mny/ (in /mnYà/ 'mouth')

${ }^{10}$ The Margi tape contains a recording of an approximately hour-and-ahalf long elicitation session conducted by Alfred Opubor and Peter Ladefoged with two Margi speakers, Sulemanu Duhu Abber and Bitrus Lassa Indaju. Elicitation is primarily through Hausa, but English is also used as the only language common to all four participants. The participants frequently talk over one another during this session, and signal to noise ratio is rather variable. The tape was analyzed by careful aural procedures, copying sections to a repeating digital playback loop and gating out words, syllables and segments for isolated attention. In addition wide-band spectrograms were made of all items of interest. 
there is a clear change from initial //m/ to final /ny/ . Each portion has a duration of at least $100 \mathrm{~ms}$. The nasal portions of the sequences /md/, /mt/ (as in /mdà/ 'surpass' or /mtàgà/ 'bush')ll are clearly auditorily labial throughout their duration. If they were produced with a simultaneous alveolar articulation, the effective resonance chamber in front of the nasal air escape would be the same as that for an alveolar. The auditory effect would therefore be like an alveolar. The stop portions show only alveolar characteristics. Since these sequences are not homorganic, an argument based on this supposition naturally fails.

There is another problem with the argument based on the data cited in (27). These forms, and all others like them, are complex compounds, containing either the genitive suffix /-r/ (\$90), or the preposition /ár/ (\$401). For example, the word for 'owl (sp.)' is a nominalized sentence

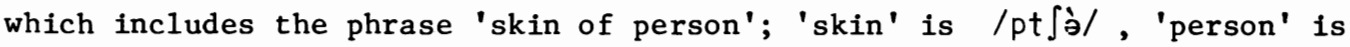
/mdà/ and the two are linked by the genitive /-r/. A boundary, normally a word-boundary, follows this suffix or the preposition. Naturally, a sequence of $/ \mathrm{r} /$ and any segment or sequence that can begin a word can thus be formed. There is no special constraint on what can follow /r/ over and above the constraints that apply at the beginning of words.

The question thus becomes whether there is any evidence that word-initial labiocoronals are single segments or sequences. We will present only one brief argument. Consider the verb /bdò/ 'chew'. This begins with a labiocoronal element which in Ladefoged's and Sagey's view is a doubly-articulated labial-alveolar implosive [ $\hat{6 f}]$. If a single segment this would be expected to have a similar duration to other implosives. We may observe its duration reliably by measuring the medial occurrence in the reduplicated participial form /bdòbdò/ 'chewed'. The duration of the intervocalic consonant(s) was measured in four tokens of this word (two by each speaker) and compared with the medial $/ \delta /$ in each speaker's reading of the word /dàdàhə̀/ 'bitter', also a reduplicated form. The duration of /bd/ is

${ }^{11}$ In initial position $/ \mathrm{m} /$ is normally voiceless before $/ \mathrm{t} /$ or $/ \mathrm{p} /$, and $/ \mathrm{n} /$ is voiceless before / $/$ / The same rule applies in Bura. 
over twice the duration of $\delta$; the former ranging from 175 to $200 \mathrm{~ms}$, the latter measured at 65 and $75 \mathrm{~ms}$ duration. The extended duration of /bd/ requires an explanation, and a natural one is that this is a sequence of two consonants, rather than a single one.

4. Conclusion

Sagey [1986] argued that there were complex labiocoronal segments in Margi and that therefore the feature hierarchy [Clements 1985] must allow for these, that is, it must allow for segments which have both labial and coronal nodes below the place node. For Sagey, the question became important primarily because of the questions raised in ensuring that the distinction between a doubly-articulated labiocoronal segment and a labialized coronal segment, i.e. one with a secondary articulation, was represented. In other words it came down to ensuring that the correct degree of stricture was assigned to the labial articulation in these two cases. If the feature hierarchy is redesigned to include a secondary articulation node, as suggested by Archangeli \& Pulleyblank [1986], this particular problem becomes moot. However, we may also note that it should not have arisen in connection with Margi. An understanding of the Margi vowel system and the role of secondary articulations in the phonology and morphology of the language removes the basis of one of the arguments in favor of interpreting the labiocoronals as single segments. Observations of the phonological and phonetic patterns of syllabification remove the other. 


\section{REFERENCES}

Archangel1, Diane and Douglas Pulleyblank. 1986. "The content and structure of phonological representations." Ms., University of Arizona (Tucson) and University of Southern California (Los Angeles).

Barreteau, Daniel. 1978. "La transcription d'un texte mofu-gudur: problèmes linguistiques." In H. Jungraithmayr \& J-P. Caprile (eds.), Cinq Textes Chadiques (Cameroun et TChad), pp. 7-71. Marburger Studien zur Afrika- und Asienkunde, Serie A, Band 12. Berlin: Dietrich Reimer.

Carnochan, Jack. 1951. "A study of quantity in Hausa." Bulletin of the School of Oriental and African Studies 13:1032-1044.

Chomsky, Noam and Morris Halle. 1968. The Sound Pattern of English. New York: Harper and Row.

Clements, G.N. 1985. "The geometry of phonological features." Phonology Yearbook 2:225-252.

Halle, Morris. 1983. "On distinctive features and their articulatory implementation." Natural Language and Linguistic Theory 1:91-105.

Haller, Beat. 1980. "Phonology of Zulgo." Summer Institute of Linguistics, Yaounde, Cameroun.

Hoffman, Carl. 1963. A Grammar of the Margi Language. London: Oxford University Press for International African Institute.

Hoskison, James. 1974. "Prosodies and verb stems in Gude." Linguistics $141: 17-26$.

Jarvis, E. 1981. "Some considerations in establishing the basic word order of Podoko." Studies in African Linguistics 12:155-167.

Ladefoged, Peter. 1968. A Phonetic Survey of West African Languages. West African Language Monographs, 1. Cambridge: Cambridge Untversity Press.

Maddieson, Ian. 1983. "The analysis of complex phonetic elements in Bura and the syllable." Studies in African Linguistics 14:285-310.

Mohrlang, Roger. 1972. Higi Phonology. Studies in Nigerian Languages, 2. Zaria: Institute of Linguistics and Kano: Centre for the Study of Nigerian Languages.

Newman, Paul. 1972. "Syllable weight as a phonological variable." Studies in African Linguistics 3:301-323.

Newman, Paul. 1977. "Chadic classification and reconstruction." Afroasiatic Linguistics 5(1):1-42.

Pulleyblank, Douglas. 1986. Tone in Lexical Phonology. Dordrecht: Reidel.

Sagey, Elizabeth C. 1986. "The representation of features and relations in non-1inear phonology." Ph.D. dissertation, M.I.T. 
Schuh, Russe11 G. 1971. "Towards a typology of Chadic vowel and tone systems." Unpublished Ms., Department of Linguistics, University of California, Los Angeles.

Schuh, Russell G. 1978. "Bade/Ngizim vowels and syllable structure." Studies in African Linguistics 9:247-283.

Schuh, Russell G. 1987. A Grammar of Miya. Monograph in preparation, Department of Linguistics, University of California, Los Angeles.

Steriade, Donca. 1987. "Redundant values." Chicago Linguistic Society 23 : 339-362. 
